\title{
PHONETICS OF SHORT $A$ IN SANSKRIT
}

1. Prof. K. C. Chattopadhyaya in his article 'Did Pānini Envisage 'A' as a Close (samurta) Vowel?' [Charudeva Shastri Felicitation Volume, Delhi, 1974, pp. 194-205; henceforth: Chattopadhyaya (1974)] has dealt with the question of short $a$ in Pạnini's system. His conclusion is that the short $a$, like long $\bar{a}$ and extralong $\bar{a} 3$, was an open (vivrta) sound for Pānini, and that Kātyāyana and Patañjali are wrong in holding that the short $a$ was a closed (samvrta) sound for him. In support of his thesis, K. C. Chattopadhyaya has

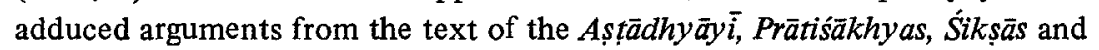
Historical Linguistics. This is a very vital point in the history of Sanskrit language and in the history of the Paninian tradition, and, therefore, I plan to discuss K. C. Chattopadhyaya's arguments in detail. With all respect for the great scholar, I beg to differ from his conclusions. I hope the following discussion will help restore the true explanation of the sound $a$ in Pannini's grammar.

2. Before proceeding to examine K. C. Chattopadhyaya's arguments, let us clearly understand the position of the Pāninian tradition. ${ }^{1}$ The tradition believes that the sound $a$ is a closed (samvrta) sound, while $\bar{a}$ and $\bar{a} 3$ are open (vivrta) sounds. In this context, the terms samvrta 'closed' and vivrta 'open' are used with reference to the size of the gap between the point of articulation (sthāna) and the articulator (karana), and thus they refer to two types of internal effort ( $\bar{a}$ bhyantara-prayatna). Thus the sounds $a$ and $\bar{a}$ differ in their internal effort. Pānini defines the term savarna 'homogeneous' in P.1.1.9 (tulyāsyaprayatnam savarnam). This rule says that two sounds are homogeneous (savarna) with each other, if they share the same point of articulation and internal effort. [I have independently treated problems of defining and implementing the concept of homogeneity in Pāninian and non-Pāninian grammars and the traditions of the Prātiśäkhyas and Sikșās in a forthcoming monograph. ${ }^{2}$ ] Since $a$ and $\bar{a}$ do not share the same internal effort, they cannot be called homogeneous with each other by P.1.1.9.

1 See: Siddhānta-kaumudī on P.8.4.68, Vol. I., pp. 17-18, [publ. by Matilal Banarasidass, Delhi, 4th edn., 1961].

${ }_{2}$ Madhav Deshpande, Critical Studies in Indian Grammarians, I, Theory of Homogeneity [savarna], and its Historical Development, to be published soon by the Center of South and Southeast Asian Studies, University of Michigan, Ann Arbor. 
P.1.1.69 (an-udit savarnasya cāpratyayah) says that an $a-N$ sound and a sound marked with $U$ stands for itself and its homogeneous sounds, if it is not an affix. Though $a$ is an $a-N$ sound, it would not be able to stand for $\bar{a}$ and $\bar{a} 3$. However, Pānini wants $a$ to stand for $\bar{a}$ and $\bar{a} 3$. For that purpose, he needs to have all these to be savarnas. In order that $a$ and $\vec{a}$ should be savarna "homogeneous", Pănini pronounces $a$ as an open sound within the sphere of his grammar. The final rule of his grammar, P.8.4.68 ( $a$ a) prescribes that open $a$ be replaced by a closed $a$. This rule is asiddha "as if non-existent" for the rest of the preceding grammar, but is siddha: "effective" for the expressions in the object language, the final output of Pānini's grammar. Thus, within the limits of his grammar, this fictional open $a$ is of metalinguistic significance, while the fiction ends by P.8.4.68, and there is no open $a$ in the object language. ${ }^{3}$ K. C. Chattopadhyaya thinks that Pănini himself did not have this concept of closed $a$ in the object language. His object language had an open $a$ which was naturally homogeneous with $\bar{a}$ and $\bar{a} 3$. He thinks that the procedure described above is a creation of Kātyāyana and Patañjali or of someone preceding them.

3. The starting point of K. C. Chattopadhyaya's argument is that the rule P.8.4.68 $(a a)$ is not a genuine part of the original Asțāahyāy $\bar{i}$, which, he thinks, ended with P.8.4.67 (nodātta-svaritodayam a-gārgya-kāśyapagälavānām). In support of his argunnent, Chattopadhyaya quotes Patañjali's discussions on P.1.1.1 and P.1.3.1. ${ }^{4}$ In P.1.1.1 (vrddhir ād-aic), the logical order of words should have been $\bar{a} d$-aic vrddhih, like P.1.1.2 (ad-en gunah), i.e. the sounds to be given a designation should come first and then the designation. On this rule, Patañjali says that Pannini changed the word order so that his grammar may begin with an auspicious word. ${ }^{5}$ Patañjali, on P.1.3.1, makes a general observation that the Śástras should begin with an auspicious word; in the middle they should have an auspicious word, and they should end with an auspicious word. ${ }^{6}$ With this background, Chattopadhyaya says: ${ }^{7}$

\footnotetext{
3 Deshpande (1972), pp. 230, 233.

4 Chattopadhyaya (1974), pp. 196-7.

5 etad ekam àcāryasya mañgalārtham mrsyatām/māngalika ācāryo mahatah sāstraughasya mañgalärtham vrddhi-śabdam àditah prayunkkte, "This one [irregular usage] of the teacher for the sake of auspicious [beginning] may be excused. The teacher with auspicious intentions uses the word vrddhi 'prosperity' in the beginning for the auspicious [opening] of the great tradition [lit. current, flow] of the śastra." Mahäbhāsya on P.1.1.1, Vol. I., Sec.,I., p. 110.

${ }_{6}$ On P.1.3.1 [bhūvādayo dhätavah], Patañjali says: mañgalädīni mañgala-madhyāni mangalōn täni śästrāni prathante, "The śästras are known to begin with an auspicious word, to contain an auspicious word in the middle and to end in an auspicious word." Mahäbhāsya, Vol. I., Sec. II., p. 111.

7 Chattopadhyaya (1974), p. 197.
} 
It is to be noted that Pănini has used here [in P.8.4.67] and here alone the word udaya in place of the term para or uttara for what comes subsequently. The word uday $a$ has been used in this sense in the Prätišakhyas. Udaya also means 'rise', 'prosperity', the same as vrddhi. It is thus a mangalärthaka word. It is with this sütra containing a mangalärthaka word udaya that Pạnini must have concluded his work.

To explain the addition of P.8.4.68 ( $a a)$, he says: ${ }^{8}$

The sütra ' $a a^{\prime}$ ' (8.4.68), therefore, was added by persons who were surprised that Pannini had assumed in his grammar that $a$ was of the same character as $\bar{a}$ and $\bar{a} 3$, whereas they pronounced it as a samivrta vowel. Pānini was a native of Sāātura, near Attock in north-western India. His pronunciation must have been different from that current in eastern and southern India. Kätyayy ana and Patañjali could not have had the same habit of pronunciation which Pannini had in the extreme north-west. They, therefore, had no difficulty in accepting as genuine Sütra ' $a a^{\prime}$ ' (8.4.68).

Chattopadhyaya thus tries to drive home the point that Pānini had open short $a$, but in later times, in eastern and southern India, short $a$ was pronounced closed (samvrta). Hence the rule P.8.4.68 $(a a)$ was invented and inserted in the Aștāahy $\bar{a} y \bar{i}$ in post-Pāninian times.

4. Before we examine Chattopadhyaya's argument, it may be mentioned that a similar argument had been given by H. Sköld to prove that P.8.4.68 did not belong to the original text of the Astāahy $\bar{a} y \bar{i}^{9}$ He went to the extreme that he rejected the latter half of P.8.4.67. He held that the Astāadhyāy $\bar{i}$ ended with the word udayam, and hence the original P.8.4.67 was thought to be only nodātta-svaritodayam, the other part a-gārgya-kāsyapa-gālavānām being considered to be a later addition. ${ }^{10}$ This view is contradicted by Sköld's famous theory of bhāsye na vyäkhyātam: rules which were not commented upon by Patanjali did not belong to the original Astāadhyāy $\bar{i}^{11}$ However, Kătyāyana and Patañjali have both commented upon P.8.4.68. K. Madhava Krishna Sharma has a detailed refutation of Sköld's view's. ${ }^{12}$ This refutation, to some extent, applies also to Chattopadhyaya's arguments.

\section{Chattopadhyaya is apparently satisfied with the fact that P.8.4.67} contains the word udayam, but, then, the text of the Astādhyayy $\bar{i}$ does not end with the word udayam. Chattopadhyaya has not gone to the extent of suggesting that the latter half of the rule P.8.4.67, i.e. a-gārgya-kāsyapagālavānām, is a later addition. If Pānini supposedly changed the word-order in P.1.1.1 to have the word vrddhi first, why did he not attempt to have the word udayam placed at the end of P.8.4.67? Thus, Chattopadhyaya's

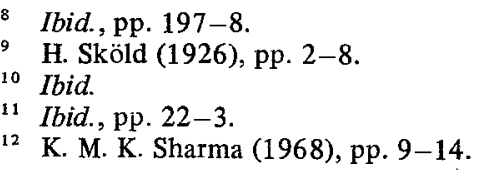


argument based on the concept of marigalānta 'auspicious ending' does not hold good for P.8.4.67.

On the other hand, P.8.4.68 $(a \mathrm{a})$ itself could be considered as an auspicious ending of the Astâadhyāy $\bar{i}$ Nāgesabhatta, in his Uddyota on P.8.4.68, has brought out the auspicious character of the sound $a .^{13}$ He says that $a$ stands for Viṣnu, and Pāninin's rule repeats this name of Viṣnu twice. He also refers to a passage from the Aitareya-Aranyaka, which says that the sound $a$ is all the speech itself, and being manifested through stops and sibilants it becomes manifold. ${ }^{14}$ To this may be added a passage from the Bhagavad-Gīta where Krsna says that he is the sound $a$ of all sounds. ${ }^{15}$ Nandikeśvara's commentary Käsikik on the Śiva-sütras also brings out the auspicious significance of the sound $a{ }^{16}$ Thus P.8.4.68 has a legitimate claim to be the auspicious end of the Astãdhy $\bar{a} y \bar{i}$.

6. After establishing the legitimate claim of P.8.4.68 $(a a)$ to be the auspicious end (maingalānta) of Pānini's grammar, we may turn to other arguments of Chattopadhyaya. He says: ${ }^{17}$ "A difference in pronunciation in different areas is as likely as in matters of accidence and syntax. . . . Hence it is quite possible that in Pānini's time $a$ was an open vowel in north-western India." Apart from this vague general claim of possible regional differences in pronunciation of Sanskrit, Chattc padhyaya has not adduced substantial evidence that $a$ in north-western India was an open sound in Pänini's time. In modern times, except in Bengal, the short $a$ sound is uniformally a closed sound. Chattopadhyaya has noted this fact himself. ${ }^{18}$ This also does not support his case.

P.8.4.68 is not only commented upon by Patañjali, but also by Kātyāyana.

${ }_{13}$ evam sūtra-kārenāpi viṣnu-vācakäkārasya dvir uccāranād dvir visnu-smarana-rūpam màngalam àcaritam. kim ca 'akāro vai sarvā vāk, saișā sparśosmabhir vyajyamānā nānārūpā bhavati' iti śruter akārasya sarva-śabda-prakrtitvāt, a iti brahmeti śabda-brahmarüpatva-śravanāe ca mahā-mañgalārthatā, "Thus by repeating twice the sound $a$ which denotes Viṣnu, the author of the sütras has performed an auspicious act in the form of twice remembering Vișnu. Moreover, [the utterance of the sound $a$ ] has an exceedingly auspicious purpose, since the sound $a$ is the primal material of all the sounds on the authority of the following Vedic passage: 'The sound $a$ is indeed all the speech; it becomes manifold being manifested through stops and sibilants', and also because it is learned from the Vedic scriptures such as: ' $a$ is brahman' that [the sound $a$ ] is of the nature of the śabda-brahman 'sound as the ultimate reality'." Uddyota on Mahäbhāșya on P.8.4.68, Vol. III., p. 511.

14 Ref. to fn. 13. The passage akâro vai sarvã vāk etc. is from Aitareya-Āranyaka 2.3.6.

1 s akșarānām akāro 'smi, Bhagavad-Gîtā 10.33 .

16 Nandikeśvara's Käśikā with a commentary by Upamanyu, Mahābhäșya, Vol. I., Nirnaya Sagara Press edn., ed. by Paṇ̣ita Sivadatta D. Kudāla, Bombay, 1917, pp. 333ff.

${ }_{17}$ Chattopadhyay a (1974), p. 198.

18 Ibid., p. 194. 
Kātyāyana mentions objections against this rule and attempts to find solutions to these objections. ${ }^{19}$ It seems that the rule was held to be an integral part of Pānini's grammar long before Kātyāyana. Kātyāyana's final vārttika on the Astāalhyāy $\bar{i}$ tries to justify the form of the rule as it stands, and specifically refers to the rule as belonging to Bhagavān Pānini. ${ }^{20}$ Some of the modern scholars like Vidya Niwas Misra characterize this rule as an unimportant phonetic observation. ${ }^{21}$ However, Kātyāyana and Patañjali realized its functional value in Pānini's grammar, and there is no reason to doubt Kātyāyana's or Patañjali's interpretation of the rule.

7. Patanjali says that an open $a$ is not found either in the Vedas or in the common spoken language. ${ }^{22}$ Chattopadhyaya characterizes this as "an uninformed boast" and remarks: "There is ample evidence about its vivrta character in the Vedas." ${ }^{23}$ However, as we shall see, Chattopadhyaya's evidence is absolutely inconclusive. He quotes instances of $a$ and $\bar{a}$ freely alternating in the Rgveda, and thinks that this could not be possible if one was closed and the other open ${ }^{24}$ [viśváha (3 times), viśváha (14 times) and viśva $\bar{a} \bar{a}(15$ times)]. Similarly, for metrical reasons, $a$ is sometimes lengthened into $\bar{a}^{25}$ [araik (in the Padapātha), arraik (in the Saminitā)]. These examples cannot prove that $a$ must be open in the Rgveda. Even if $a$ were a closed sound, still $\bar{a}$ is the nearest vowel to alternate with it. We have alternations like sürya/süriya, despite the fact that $y$ and $i y$ do not have the same internal effort.

Chattopadhyaya points out that the Sanskrit diphthongs contain the sound $a$. Then he remarks: " "The mutation of $e(=a-i)$ into $\bar{a} 3 i$ or of $o$ $(=a-u)$ into $\bar{a} 3 u$ was possible because the first element $a$ in these diphthongs was of the same nature as $\bar{a} 3$, i.e. vivrta." Many texts support that diphthongs were more open than other vowels. ${ }^{27}$ We can agree that the element $a$ in these diphthongs was an open sound, though there were phonetic traditions which held that $a$ in $a i$ and au was samvrta-karana-tara "with a more closed

19 Deshpande (1972), pp. 226, 230 and 233.

${ }^{20}$ ekaśesa-nirdeśád vā svara-bhinnānä̀m bhagavatah pānineh siddham, Vārttika 4 on P.8.4.68.

${ }_{21}$ "Nevertheless Sköld's observation that the last sütra (VIII.4.68) is extraneous to the Asțādhyāyì seems to be well founded, as this sütra gives a phonetic observation that is not relevant to the analysis." V. N. Misra (1966), p. 20.

${ }_{22}$ naiva loke na ca vede 'käro vivrto 'sti, Mahäbhäsya, Vol. I., Sec. I., p. 64.

${ }^{23}$ Chattopadhyaya (1974), pp. 198-9.

24 Ibid.

25 Ibid.

26 Ibid., pp. 199-200.

${ }_{27}$ For instance: Śaunakīyā Caturādhyāyikā (i.34) [ekāraukārayor vivrtatamam \; Rktantra (i.3) [vivrtataram akāraikāraukārāạăm] . 
articulator". ${ }^{28}$ However, this cannot prove in any logical way that $a$ as an independent sound had to be open. Patañjali accepts components of diphthongs to be vivrtatara 'more open', and yet he declares that $a$ as an independent sound is open neither in the Vedic nor in the spoken language. ${ }^{29}$ Chattopadhyaya's arguments seem to be based on analogy and are not sound. This may be compared with the sounds $r$ and $r$. Some texts considered $r$ as being danta-mūliyya 'produced at the root of the teeth', but $r$ and $l$ both as being jihv $\bar{a}-m \bar{u} l \bar{l} y a$ 'produced at the root of the tongue' $\cdot{ }^{30}$ Other texts consider both $r$ and $r$ to be mürdhanya "cerebral'. 31 Yet the rules which give relations between $r$ and $r$ are the same. Despite the difference of opinion on the point of articulation of $r$ and $r$, all texts agree that $n$ changes to $n$, if preceded by $r, r$ and $s$. Thus it would be a mistake to claim that one could infer exact phonetic details from grammatical features of written literature. Such inferences can never be stronger than the explicit statements of ancient Indian phoneticians.

8. Chatiopadhyaya discusses the Prātiśăkhyas and Siksās to some extent and tries to conclude that these texts generally support his theory of open (vivrta) short $a$. On this point there has been great difference of opinion from the time of Weber and Whitney. Traditionally, there is a dichotomy between different texts on this point. Texts which are held to stand for closed $a$ and open $\bar{a}$ are the Astā $\bar{a} h y \bar{a} y \bar{i}, V \bar{a} j a s a n e y i-p r a \overline{t i s} \bar{a} k h y a$ and the Saunak $\bar{i} y \bar{a}$ Caturādhyāyikā, while the Rgveda-prātiśäkhya and the Taittirìya-prātiśākhya do not clearly distinguish the quality of $a$ from that of $\bar{a}$. Whitney comments: ${ }^{32}$ "But it is very doubtful whether we are to regard the silence of these two treatises upon the point in question as any evidence that they are of notably earlier date than the others, as Weber seems inclined to do: their peculiarity is much more likely to be due to a local or a scholastic difference of pronunci-

28 Taittiriya-prātišäkhya (ii.27) [saínrta-karana-taram ekesām] .

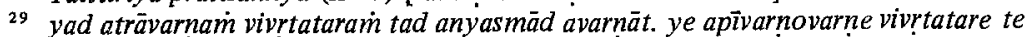
anyābhyām ivarnovarnäbhyām, "The $a$-vowel that is in here (i.e. in a diphthong) is more open than other $a$-vowels. Similarly, the $i$-vowel and the $u$-vowel that are [in here] are more open than other $i$-vowels and $u$-vowels." Mahäbhāsya, on the Siva-sütra: $e-o-N$, Vol. I., Sec. I., p. 64. See fn. 22 for Patanjali's statement on independent $a$ being always a closed sound.

30 rkäralkärāiv atha saștha ūsmā jïhvā-mülīyah prathamaś ca vargah, Rgveda-prātisákhya, 1.8 and danta-mūlìyas tu tak̄ōra-vargah. sakära-repha-lakārāś ca, Rgvèda-prātiśäkhya, $1.9-10$.

jihvī-müle h-k-r, Rktantra, 2.4 and repho (danta-) müle vā, Rktantra, 2.8.

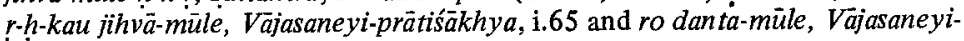
prätiśákhya, 1.68 .

${ }_{31}$ r-tu-ra-șăh mürdhanyāh, Apiśali-śikșā-sūtra, 8, Sthäna-prakarana, Síiksā-süutrāni, p. 2,

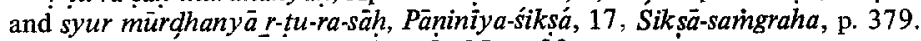

${ }^{32}$ Whitney, Saunakty $\bar{a}$ Caturădhyà $y i k \bar{a}$, p. 32. 
ation, or they may have simply disregarded as of little account, the discordance of quality between $a$ and $\bar{a}$." In this remark, Whitney has hinted at many different possibilities, without coming at a definite conclusion. ${ }^{33}$ Max Walleser has considered these alternatives and he concludes as follows: 'Mir scheint nun nur die an zweiter Stelle gegebene Erklärung angängig zu sein, nämlich die Annahme, dass der Unterschied in der Aussprache schon in der ältesten Zeit bestanden habe, aber erst nach der Zeit der Rk. und Taitt. Pr. bemerkt worden ist, und zwar aus vier Gründen: . . .', Walleser (1927, p. 195). I tend to agree with his general conclusion, but, unfortunately, his 'vier Gründe' are not very convincing. He seems to believe that no sound changes are heard of or have been observed within the 'Literaturschicht der Prātiśākhyen', and that the Vedic speech being a dominating 'Kultsprache', any organic sound changes were generally unlikely. The arguments adduced by him to prove that the Sanskrit short $a$ was a closed sound are based on the historical relationschip of the Sanskrit $\stackrel{x}{a}$ with Indo-european $a, e$ and $o$. The thrust of the argument is that the Sanskrit short $a$ is the Indo-european Schwa, which is described by linguists as an 'unbestimmten Vokal' or as an 'unvullkommen gebildeten Vokal' (Ibid., p. 197). For this reason it as if concealed the distinctions of the Indo-european $a, e$ and $o$. I am not yet convinced of the historical validity of this argument.

9. Chattopadhyaya says: ${ }^{34}$ "The R Rk Prātiśākhya uses the terms vivrta and sarivrta about consonants only and not about vowels." This is not quite correct. The Rgvedaprātiśäkhya says ${ }^{35}$ that the glottis could be open (vivrta), closed (saimvrta), or in between. If it is closed (saívrta), then nāda 'resonance' is produced. If it is open (vivrta), then śvasa 'unintonated breath' is produced. If the glottis is in between, both of these are produced. The emission of $n \bar{a} d a$ 'resonance' is shared by vowels (svara) and voiced (ghosavat) consonants, while śvāsa 'unintonated breath' is shared by unvoiced (aghosa) consonants. Thus, the description of glottis being closed (samvrta) applies to all the vowels. However, this is not the same as samvrta-prayatna "closure as an internal effort', which refers to a minimal gap between the articulator and the point of articulation. The Rgveda-prātiśäkhya classifies vowels, sibilants and

\footnotetext{
33 The chronology of the Prātiśákhyas is still not settled definitively and that makes it hard to decide this question.

${ }^{34}$ Chattopadhyaya (1974), p. 200.

${ }^{35}$ vāyuh pränah koșthyam anupradānam kanthasya khe vivrte samivịte vāāâpadyate

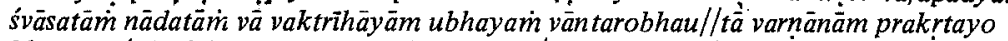
bhavanti śväso'ghoșānām itaresām tu nādah/,Rgveda-prätišákhya, 13.1-2. The word itareșām is explained by Uvața with svarānām ghoṣavatām $c a$ vowels and voiced consonants'. Also see: Taittiríya-prātiśäkhya 2.8 .
} 
anusvära as being asprsta 'without contact', stops as being sprsta 'with contact' and semi-vowels as being duhsprsta "with obscured contact." Thus $a$ and $\bar{a}$ are both asprsta 'without contact' between the articulator and the point of articulation. However, this does not necessarily mean that there could not have been a difference in the size of the gap. Despite having a small and a big gap, both could be classified as being 'without contact'. Thus, we can never be sure if there was any difference or not in the size of the gap. The concept of non-contact does not permit any subclassification, but the concept of a gap or openness does permit such a subclassification. ${ }^{37}$

10. The Rktantra, ascribed to Śäkatāyana, shows some terminological development. It uses the terms samvrta and vivrta in the context of glottal aperture. ${ }^{38}$ But it extends the term vivrta to the gap between the articulator and the point of articulation. It replaces the older notion of asprsta "without contact" with vivrta "open'. It says that all vowels and sibilants are vivrta. ${ }^{39}$ It also says that akāra, e/aikāra and o/aukāra are vivrtatara 'more open' ${ }^{40}$ This is a very strange statement. Literally it means that $a$ is more open than $\vec{a}$. Is it possible that the term akāra is used in the sense of avarna, or is it a misreading for $\bar{a} k \bar{a} r a$ ? It is hard to answer this question. The stage of the Rktantra still seems to be quite primitive. There is no differentiation in the efforts of vowels and sibilants, and openness has only two types: open and more open. It is possible that this terminological underdevelopment is responsible for not differentiating $a$ from $\bar{a}$ qualitatively. For this reason, I cannot accept the $R k$ tantra statements as indicating definitive identity of the internal efforts of $a$ and $\bar{a}$.

11. The Taittirìya-prātiśäkhya extends both samirta and vivrta from glottal aperture ${ }^{41}$ to internal efforts. It distinguishes the effort of vowels from that of all the other consonants. It describes all vowels as having

${ }^{36}$ tad-viseșah karanamin sprștam asthitam, duhspṛțtam tu prāgghakärāc caturnām. svarānusväroșmañäm asprștaì sthitam, Rgveda-prātiśäkhya, 13.3.

37 The asprsta 'non-contact' classification of vowels is probably the older classification, and it is gradually seen being replaced by the more advanced categories such as vivrta 'open', vivrtatara 'more open', vivrtatama "most open" and sainvrta 'closed'.

This is my personal judgement. However, in the available recorded documents, the term vivrta 'open' appears first. What is not clear is whether it stands for glottal openness or for openness as an internal effort. For details, ef. Madhav Deshpande, 'New Material on the Kautsa-vyākarana', appearing in the Journal of the Oriental Institute, Baroda, (1975?).

${ }^{38}$ saminto ghoșavän, vivrto'ghoșah, Rktantra, 1.3 .

39 vivrtaim svarosmanām, Rktantra, 1.3 .

40 vivrtataram àkäraikāraùkārānām, Rktantra, 1.3.

41 sam̉vte kaṇthe nādah kriyate, vivrte śvāsah, Taittirīya-prätiśākhya, ii.4-5. 
upasaminara 'approximation' between the point of articulation and the articulator, while all other consonants have sparsana 'contact' ${ }^{42}$ It says that the middle of the articulator is vivrta 'open' in the case of sibilants, while the rest of the articulator is still with sparsana 'contact'. ${ }^{43}$ This is what distinguishes sibilants from the other consonants. It states that according to some phoneticians $a$ in $a i$ and $a u$ is samvrta-karana-tara 'with a more closed articulator'. ${ }^{44}$ This could mean that the normal $a$ was samvrta, despite Whitney's remarks to the contrary. ${ }^{45}$ Chattopadhyaya considers this rule (ii.27) to be an interpolation, because the word samvrta-karana-tara is used without ever defining or using elsewhere the term samvrta. ${ }^{46}$ This is a very weak argument. This text has used many terms without defining them, and it would be catastrophic to consider all such rules as interpolations. Pänini has also used many technical terms without defining them; such terms are ascribed to pūrvācāryas 'previous teachers' by the commentators, implying that they were well established before Pānini wrote his grammar. The rule (ii.12) of the Taittirìya-prätisâkkhya litterally says that in the case of a-vowels (avarna), lips and jaws are neither too closed, nor too much apart. ${ }^{47}$ Chattopadhyaya quotes Whitney on this rule to show that this rule does not indicate $a$ as a closed sound. ${ }^{48}$ However, contrary to Whitney's comments, all the three available commentaries on the Taittiriy a-prätišäkhya interpret the rule to mean that $a$ is not 'too closed', and $\bar{a}$ and $\bar{a} 3$ are not 'too open'. ${ }^{49}$ This indicates that there is a possibility of $a$ being closed and $\bar{a}$ being open, despite the

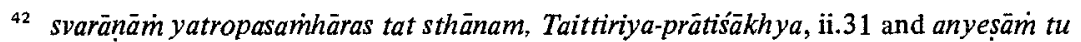
yatra sparśanam tat sthānam ibid., ii.33.

${ }_{43}$ karana-madhyam tu vivrtam, Taittirìya-prätisák khya, ii.45.

44 samvrta-karana-taram ekesām, Taittiriya-prātiśākhya, ii.27. The previous rule (ii.26)

says that there is a half-mora quantity of $a$ in the beginning of $a i$ and $a u$. The rule (ii.27) says that this half mora of $a$ is a 'more closed' sound according to some. The natural interpretation of this would be that for others this $a$ was not 'more closed'. The real question is whether it was 'open' or 'closed'. The comparative degree in the expression samvrta-karana-tara can be better justified if normal $a$ were a 'closed' sound, contrasting with this 'more closed' occurrence.

45 Whitney on the Taittirìya-prātiśấkhya, ii.27, p. 65.

46 Chattopadhyaya (1974), p. 201.

${ }^{47}$ avarne nāty-upasamintam oștha-hanu nāti-vyastam, Taittirìya-prātišâkhya, ii.12. "In forming the a-vowels, the lips and jaws must not be too nearly approximated, nor too widely separated." Whitney's translation, Taittiriya-prātiśákhya, p. 55.

48 Chattopadhyaya (1974), pp. 201-2.

${ }_{4} 9$ akâre nāty-upasamhrtam, äkāre ca plute ca nātivyastam/, Tribhāsyaratna on the Taittiriya-prätiśákhya, ii.12, p. 55.

akāre nāty-upasaminhrtah, ākâre ca plute ca nātivyastah, Mãhiseya's Padakramasadanabhăsya on the Taittirìya-prätiśák hya,[Madras edn.], p. 19, hrasve avarne upaśleșa-

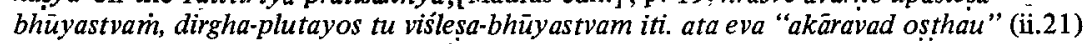

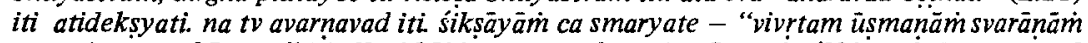
ca, samurtam akārasya" iti, Vaidikābharana on the Taittirīya-prātiśákhya [Mysore edn.], p. 73. The commentary Vaidikäbharana has brought out an important piece of evidence to show that this text does differentiate $a$ and $\bar{a}$ qualitatively. The rule (ii.21) says that 
explicit statement that they both have approximation (upasamināra) between the point of articulation and the articulator. There can be different degrees of approximation..$^{49} \mathrm{a}$

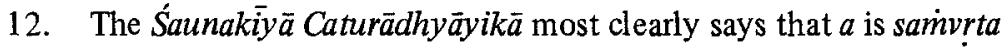
'closed', while $\tilde{a}$ is the most open (vivrta) of all sounds. ${ }^{50}$ Chattopadhyaya has accepted this fact. ${ }^{51}$ This text is identical with the Vyäkarana ascribed to Kautsa. ${ }^{52}$ Patañjali has quoted this text in his Mahäbhāsya. ${ }^{\dot{3}}$ Patañjali's Mahābhāsya refers to Kautsa as a student of Pānini. ${ }^{54}$ If this Kautsa is the same as the author of the Saunakīy $\bar{a}$ Caturādhy $\bar{y} y i k \bar{a}$ or Kautsa-vyäkarana, then this concept of $a$ being samvrta 'closed' can be traced to Pänini's own disciple. However, this needs more historical research. Anyway, the text clearly distinguishes $a$ from $\bar{a}$. I have checked the manuscripts of this text in the Bhandarkar Oriental Research Institute, Poona, and the Vaidika Samśodhana Mandala, Poona, and the rules in question are found in all the manuscripts.

\section{The Väjasaneyi-prätiśäkhya (I.72) [savarnavac ca] is normally inter-} preted to mean that $a$ is closed, and yet is to be treated like a savarna "homogeneous sound" with respect to $\vec{a}$ which is open. This is Uvata's explanation and has been accepted by Weber and Whitney. ${ }^{55}$ Chattopadhyaya says: ${ }^{56}$ "Whitney's reference(s) to the close character of $a$ according to sütra 1.72 is

\footnotetext{
when no special directions are given, the lips are in a position similar to the production of the short $a$, i.e. akāra. The commentary says that this rule differentiates the position of the lips in producing $a$ from the position in producing $\bar{a}$ and $\bar{a} 3$. Thus the rule specifically refers to a short $a$, and not to $a$-varna, i.e. $a$-vowels, which include $a$ and $\bar{a} 3$. ${ }^{49} \mathrm{a}$ The notion of upasamhrtatara 'more approximated' is seen in the rules Taittiriyaprātiśákhya ii.14, 16 and 18. Similar gradations are seen in ii.15 and 27. These are different gradations in 'non-contact'.

so tato'py ākārasya, samivrto'kārah, Śaunakìyā Caturādhyāyikā, i.35-6.

51 Chattopadhyaya (1974), p.202.

52 Katre S. L. (1938). I have myself compared the two manuscripts of the Kautsavyākarana in the Vaidika Samiśodhana Mandala, Poona, with the manuscripts of the Saunakiya Caturädhyajyikā in this collection as well as in the collection at the Bhandarkar Oriental Research Institute, Poona. These two texts are virtually identical.

s3 Mahäbhäsya on P.1.1.10, Vol. I., Sec. I., p. 160.

${ }^{54}$ upasedivān kautsah päninim, Mahäbhāṣya on P.3.2.108, Vol. II., p. 172.

${ }_{55}$ atrākārasya mātrikasya samurrtāsya-prayatnasya itarayoś ca vivrtāsya-prayatnayor dvi mätrika-tri mätrikayoh saha sāvarnyam tulyam na sambhavatīti tadartham idam ärabhyate/savarnavac ca k̇āryam bhavati, savarna-dirghatvam bhavatity arthah/, Uvata on the Vajasaneyi-prätiśakhya, i.72, p. 29. dirghaplutayor avarnor vivrtatvam/saimvrtam hrasvasyeti bhinna-prayatnatvena dïrghādinàm sāvarnyābhàvàd vacanena săvarnyam abhihitam/, Anantabhatta's Bhäsya on the Vajasaneyi-prätiśákhya, i.72, p. 29. Also see: Whitney on the Śaunakìya Caturādhyāyikā, i.36, pp. 31-2; Vajasaneyi-prātišákhya, ed. and tr. by Albrecht Weber, Indische Studien, Band 4, Berlin, 1958. pp. 118-9.

56 Chat topadhyaya (1974), p. 201.
} 
wrong. ... Uvata's reference to the samvrta character of $a$ and the vivrta character of other vowels is against the text and has been imported from the Vārttika and the Mahābhāsya." Having thus discarded the older interpretation, Chattopadhyaya proposes a new interpretation for the rule 1.72. He says: ${ }^{57}$ "Sütras I.65 to 71 all speak about the sthāna of vowels and consonants. 'Savarnavac ca' must mean in this context, that savarna vowels, such as $a, \bar{a}, \bar{a} 3$, $i, \bar{i}, \bar{i} 3, u, \bar{u}, \bar{u} 3$, have the same sthāna of utterance." It must be pointed out that this interpretation is not correct. In the system of the Väjasaneyiprätiśäkhya we do not need a rule to that effect. The rule I.63 [hrasvagrahane dirgha-plutau pratiyat $]$ says that when in the following rules a short vowel is mentioned, it also stands for long and extra-long varieties. The rule of I.64 [prathama-grahane vargam] says that in the following rules the first of the stop-series stands for the series. Thus a rule like I.66 [icaśeyās tālau] literally says: "the sounds $i, c, s, e$ and $y$ are produced in the palate." By the rule $1.63, i$ stands for $\bar{i}$ and $\bar{i} 3$ also. Similarly, by $1.64, c$ stands for $c$-varga. Thus I.72 need not say what Chattopadhyaya makes it say. Actually, Uvata's explanation is quite sound. The sound a continues from I.71 [ahavisarjaniya kanthe] into I.72 [savarnavac ca] . By I.63, $a$ also stands for $\bar{a}$ and $\bar{a} 3$. Thus the rule naturally means: "The sounds $a, \bar{a}$ and $\bar{a} 3$ are also savarnavat 'treated like savarna'." This is a legitimate interpretation and implies that these sounds are not savarnas by the regular definition of 1.43 [samäna-sthānakaranāsya-prayatnah savarnah], which requires sounds to have the same point of articulation, the articulator and the internal effort. By I.71, $a, \bar{a}$ and $\bar{a} 3$ have kantha 'throat' as their point of articulation. The rule I.84 [kanthya madhyena] says that throatal sounds have hanu-madhya 'middle of the jaws' as their articulator. Thus the only possible difference between $a$ and $\bar{a}$ is that of asya-prayatna 'internal effort'. Thus Uvata's explanation of the rule seems to be quite natural.

14. Chattopadhyaya quotes the versified Pāniniya-sítssā to support his thesis of open $a .{ }^{58}$ The verse 21 says that vowels and sibilants are vivrta 'open', $e$ and $o$ are more open, and $a i$ and $a u$ are most open. ${ }^{59}$ However, he ignores the verse 20ab: samivrtam mätrikam jñeyam, vivrtam tu dvi-mätrikam. This line is found only in the Rgveda version of the Päninīya-siksă, and has not been explained by any of the commentaries..$^{60}$ However, Chattopadhyaya quotes

\footnotetext{
57 Ibid.

s8 Ibid., p. 202.

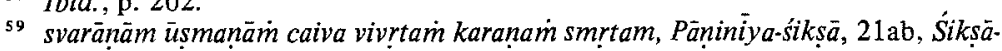
saimgraha, p 380 .

${ }_{60}$ Manmohan Ghosh (1938), p. 41. He translates this line as: "A samvrta (close) sound is one mätra long, and a vivrta (open) sound is two mäträs long." Ibid., p. 64. This is a
} 
this line and yet does not seem to realize its significance. ${ }^{61}$ It can only refer to a closed $a$ which is of one mora, and to an open $\bar{a}$ which has two moras. The Siksā-sütras ascribed to Āpiśali explicitly refer to closed $a .{ }^{62}$ The long and the short versions of the Pāninīya-sikssa-sütras also refer to closed $a^{63}$ Chattopadhyaya quotes the Cändra-varna-sütras to show that there is no closed $a{ }^{64}$ This is a misrepresentation of these sütras. Candragomin clearly refers to sarnvrtatva 'closedness' as an internal effort. ${ }^{65}$ Chattopadhyaya himself quotes this rule. ${ }^{66}$ However, the edition of these sütras used by Chattopadhyaya does not have a rule for stating that $a$ is a closed sound. He uses the edition by K. C. Chatterji [an appendix to his two-volume edition of the Cāndra-vyākarana, Deccan College, Poona, 1953, 1961]. It would be strange to have samvrta on the list of internal efforts, and not have any sound possessing it. I have checked three other editions of these sütras, and all of them have the rule samvrtatvam akārasya "the internal effort of $a$ is saimvrtatva 'closedness'." closed sound. 68

15. The notion of an open $a$ gained prominence among some of the Jaina grammarians. Among them, Säkatāyana alone speaks of $a$ being a closed sound ${ }^{69}$ Hemacandra holds that $a$ is an open sound, and says that others, i.e. the Päniniyas, consider it to be a closed sound. ${ }^{70}$ Hemacandra's main source is the Sikșa of Ápisali, and it is not clear why he differed from Āpisali on this point. In the rules of the Jainendra-vyākarana there is no indication of $a$

very neutral translation and does not clarify anything. If the terms samvrta and vivrta were to refer to glottal aperture, then this distinction of short and long cannot apply to this classification. This line has to refer to a closed $a$ and and an open $\bar{a}$.

${ }_{61}$ Chattopadhyaya (1974), p. 202.

${ }^{62}$ samivrto'kārah, Āpiśali-sikșā-sūtra 11, antah-prayatna-prakaranam, Śikșä-sūtrāni, p. 4.

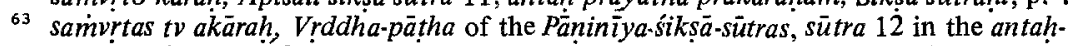
prayatna-prakarana, Sikșä-süträni, p. 12. The same sütra is found in the Laghu-pätha of the Pāninīya-sikssä-sütras, Ibid., p. 21.

${ }_{64}$ Chattopadhyaya (1974), pp. $202-3$.

65 taträbhyantarah; samurtatvam vivrtatvam sprștatvam iṣat-sprștatvam ca, Cändravarna-süträni, Śikșäsūtrāni, p. 25.

66 Chattopadhyaya (1974), p. 202.

67 Candragomin's Varna-sütras, an appendix to the Cändravyākarana, ed by Bechardas J. Doshi, Rājasthāna Purātana Grantha-mālā, No. 39, 1967, p. 81.

Cändra-varnasütras, Sikșāsūträni, p. 25.

Cāndravarnasūutras, appendix to the Päniniyasikșā, Manmohan Ghosh (1938), p. 45.

${ }_{68}$ akārah samvrto jñeya itare vivrtäh, svarāh, Yäjñavalkya-sikssa 209ab, Sikṣâ-samgraha, p. 32; akärah samuvrto jñeyo vivrtàs cetare svarāh, Varna-ratna-pradipikä-sikssā of

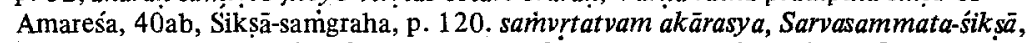
181a, Mss No: 383, 1883-84, Bhandarkar Oriental Research Institute, Poona. samvrtam cety akārasya, Saisiriya-sikșa, the Journal of Vedic Studies, Vol. 2., No. 2., August 1935, p. 3.

${ }_{69}$ samvrtatvam akārasyeti, Amoghavrtti on the Sākatāyana-vyākarana, 1.1.6, p. 3.

${ }^{70}$ akärah samvṛta ity anye, Brhad-vrtti on Hema-śabdānuśásana, 1.1.17, p. 4. 
being an open sound. But Abhayanandin, the author of the Mahāvrtti, holds that $a$ is an open sound, and criticizes Pānini for holding that $a$ was open only in grammar, while it was a closed sound in the real usage. ${ }^{71}$ Malayagiri also accepts $a$ as an open sound. ${ }^{72}$ None of the other grammars accept this view.

16. Chattopadhyaya believes that the closed $a$ came to be used in Sanskrit in post-Pāninian times. He says: ${ }^{73}$ "In view of these facts, it appears very likely that in Pānini's bhāșā $a$ differed from $\bar{a}$ only in $m \vec{a} t r a \bar{a}$ and was fully its savarna and that $a$ became a samvrta vowel later or in the eastern and southern parts of the country under the influence of Primitive Dravidian unaffected by Sanskrit scholasticism." He considers that the cerebral sounds in Sanskrit show influence of Dravidian on ancient Sanskrit. There is little disagreement on this point. But nobody has ever claimed that the closed $a$ in Sanskrit is due to Dravidian influence. As a new suggestion of Chattopadhyaya this is certainly worth exploring. However, this argument cannot be used to prove that $a$ in Pannini's time was open and it became closed later due to the Dravidian influence. The cerebral sounds and $l$, which are ascribed to Dravidian influence, appear already in the Rgveda, the oldest compositions in Indo-Aryan. If we want to ascribe closed $a$ to Dravidian sources, there is no reason why it should not be coeval with cerebral sounds. By this line of argument, we may have to push back the appearance of closed $a$ to Rgvedic times. This certainly goes against Chattopadhyaya's thesis.

17. In conclusion, we may say that there is no evidence to show that the traditional interpretation of Pānini's system concerning phonetics of $a$ is wrong. On the other hand, there is overwhelming evidence to the contrary. Chattopadhyaya thinks that $a$ was originally an open sound, which later became a closed sound. The evidence discussed above shows that it is more probable that $a$ has been a closed sound from early times, and that it became an open sound only in a province like Bengal, and in some of the Jaina

71 vivrta-karanāh svaräh, ... anye saṁvrtam akāram icchanti loke. śăstra-vyavahāre tu vivrtam etac cā̄yuktam loka-śástrayor uccāranam praty aviśeșāt., Jainendra-mahä-vrtti [on the Jainendra-vyākarana, 1.1.2] , p. 2.

72 Malayagiri's Śabdānuśásana, with the autocommentary, p. 5.

${ }_{73}$ Chattopadhyaya (1974), p. 204. Contrast Chattopadhyaya's overall assessment with the following remark of Jules Bloch: "For example, even the grammarians have noted that $a$ was more closed than $\bar{a}$ and this is confirmed in several ways, particularly by the oppositions of timbre, which nowadays replace the ancient oppositions of quality, e.g. Bengali $a, o$ opposed to $a$ (written $\vec{a}$ ), European Romany $e$ opposed to $a$. . Indo-Aryan, from the Vedas to Modern Times, [tr. from the original French by Alfred Master], Paris, 1956, p. 34. If actually the closed $a$ is due to Dravidian influence, it can be pushed back to the shift from Indo-Iranian to Indo-Aryan. The existence of Brahui and Elamite in the Iranian regions and other similar facts may lead us to believe that the migrating Aryans might have come into contact with Dravidians even before they entered India proper. 
traditions. We must be thankful to Chattopadhyaya for his novel suggestion that this closed $a$ may be due to Dravidian influence on old Sanskrit. This certainly needs further exploration in the ancient linguistic history of Sanskrit, Iranian and Dravidian, and must be accepted at this stage only as a hypothesis.

Univ. of Michigan, Ann Arbor

\section{BIBLIOGRAPHY}

Original Sources:

Cändra-vyākarana, by Candragomin, ed. by Bechardas Doshi, Rajasthan Puratan Granthamalä, Jodhpur, 1967.

Hema-śabdānuśásana, by Hemacandra, Hemacandrānanda-granthābdhau trīìyam grantharatnam, ed. by Chandra Sagara Suri, Ujjain, Vikrama Samvat 2007.

Jainendra-mahāvrtti, by Abhayanandin, Jñānapìtha Mürti-deví Grantha-mālä, Sanskrit Text 17, Banaras, 1956.

Mahābhāşya, by Patañjali, with Pradipa by Kaiyața, and Uddyota by Nāgeśa, edited in three vols, Motilal Banarasidass, Delhi, 1967.

Rgveda-prätiśăkhya, text only, ed. by M. D. Shastri, pt. I., Banaras, 1959.

$\dot{R} k$ tantra, by Śäațāyana, ed. by Surya Kanta, Lahore, 1933, reprinted from Delhi, 1970.

Śabdānuśásana, by Malayagiri, ed. by Bechardas Doshi, Lalbhai Dalpatbhai Series No. 13, Ahmedabad, 1967.

Śaisiriya-sikșā, ed. by Tarapada Chowdhurry, Journal of Vedic Studies, Vol. II., No. 2, Aug. 1935, Lahore.

Śakatăyana-vyākarana, by Säkatāyana, with the auto-commentary Amoghavrtti, ed. by Shambhunath Tripathi, Jñänapitha Mūrti-deví Granthamālä, Sanskrit Text No. 39, Banaras, 1971.

Saunakīy $\bar{a}$ caturā dhyāyikē, tr. and ed. with Notes, by W. D. Whitney, Journal of the American Oriental Society, Vol. VII., 1862.

Sikșā-samgraha, A Collection of Various Sikṣā-texts, Banaras Sanskrit Series, Banaras, 1893.

Śikșā-sütrāni, by Āpiśali, Pānini and Candragomin, ed. by Yudhishthir Mimamsak, Ajmer, Samvat 2024.

Taittirìya-prātišäkhya, with the comm. Tribhāsyaratna, ed. and tr. with Notes, W. D. Whitney, New Haven, 1868. [All page-references are to this edition, unless otherwise specified.]

Taittirìya-prätišăkhya, with the commentaries Tribhäsyaratna and Vaidikäbharana, ed. by K. Rangacharya and R. Rama Sastri, Government Oriental Library Series, Bibliotheca Sanskrita, No. 33, Mysore, 1906.

Taittirìya-prātiśákhya, with Māhișeya's Padakramasadanabhāsya, Madras University Sanskrit Series, No. 1., ed. by V. Venkatarama Sharma, Madras, 1930.

Vãjasaneyi-prātiśákhya, ed. and tr. into German, by Albrecht Weber, Indische Studien, Band 4, Berlin, 1858.

Vajasaneyi-prātiśákhya, with the commentaries by Uvata and Anantabhatța, Madras University Sanskrit Series, No. 5, ed. by V. Venkatarama Sharma, Madras, 1934. [All page-references are to this edition, unless otherwise specified.]

Secondary Sources:

Bloch, Jules, Indo-Aryan, from the Vedas to Modern Times, [tr. from the original French by Alfred Master], Paris, 1965. 
Chattopadhyaya, Kshetresh Chandra (1974), 'Did Pānini Envisage "A" as a Closed Sound', Charudeva Shastri Felicitation Volume, Delhi, 1974, pp. 194-205.

Deshpande, Madhav (1972), 'Pāninian Procedure of Taparakarana, A Historical Investigation., Zeitschrift fuir Vergleichende Sprachforschung, Band 86, Heft 2, 1972, pp. 207-254.

Ghosh, Manmohan (1938), Päninìya Sikssā, critically edited in all its five recensions with an Introduction, Translation and Notes, University of Calcutta, 1938.

Katre, S. L. (1938), 'Kautsa-vyākarana, A Detailed Notice; Recovery of Kautsa's Authorship', New Indian Antiquary, Vol. I., Bombay, 1938.

Misra, V. N. (1966), The Descriptive Technique of Pänini, Mouton, Paris-Hague, 1966.

Sharma, K. M. K. (1968), Pānini, Kātyāyyana and Patañjali, Delhi, 1968.

Sköld, Hannes (1926), 'Papers on Pänini, and Indian Grammar in General', Lunds Universitets Arsskrift, N.F.Avd.1., Bd.21., Nr.8., Lund, 1926.

Walleser, Max (1927), 'Zur Aussprache von skr. a.', Zeitschrift für Indologie und Iranistik, Band 5, Leipzig, 1927. 